\title{
Comparison between nab-paclitaxel and solvent-based taxanes as neoadjuvant therapy in breast cancer: a systematic review and meta-analysis
}

\author{
Miao Liu, Siyao Liu, Liu Yang and Shu Wang*
}

\begin{abstract}
Background: To compare the efficacy and safety of nanoparticle albumin-bound paclitaxel (nab-paclitaxel) and solvent-based taxanes (sb-taxanes) as neoadjuvant therapy in the treatment of breast cancer.

Methods: We systematically searched the PubMed, Embase, and Cochrane Central Register databases. Randomized controlled trials (RCTs) and cohort studies, published in English, about the comparison between nab-paclitaxel and sb-taxanes as neoadjuvant therapy in patients with breast cancer were searched up to September 2019.

Results: The primary outcome was the proportion of patients with pathological complete response ( $p C R$, defined as ypTO ypNO or ypTO/is ypNO). Other main outcomes included long-term survival and adverse events (AEs). Seven studies (five RCTs and two cohorts) and 2949 patients were included. Neoadjuvant nab-paclitaxel improved pCR compared with sb-taxanes (ypT0 ypNo: $\mathrm{OR}=1.52,95 \% \mathrm{Cl}: 1.27-1.83, P<0.001$; ypT0/is ypNo: $\mathrm{OR}=1.40,95 \% \mathrm{Cl}: 1.17-$ $1.68, P<0.001)$. The benefits of nab-paclitaxel on $\mathrm{PCR}$ were persistent in HER2-negative, hormone receptor (HR)positive breast cancer $(\mathrm{OR}=1.53,95 \% \mathrm{Cl}: 1.07-2.19, P=0.020)$, triple-negative breast cancer (weekly/every 2 weeks regimen; $\mathrm{OR}=2.95,95 \% \mathrm{Cl}: 1.54-5.67, \mathrm{P}<0.001)$, and tumors with $\mathrm{Ki}-67>20 \%(\mathrm{OR}=1.63,95 \% \mathrm{Cl}: 1.26-2.12, \mathrm{P}<$ 0.001). Patients treated with nab-paclitaxel had better event-free survival (EFS; $H R=0.69,95 \% C l: 0.57-0.85, P<0.001$ ) than with sb-taxanes. There were no differences in most of grade $\geq 3$ AEs between nab-paclitaxel and sb-taxanes (all $P>0.05)$, besides of any grade hypersensitivity $(\mathrm{OR}=0.29,95 \% \overline{\mathrm{Cl}}: 0.11-0.72, P=0.008)$, any grade $(\mathrm{OR}=2.10$, $95 \% \mathrm{Cl}: 1.37-3.23, P=0.001)$ and grade $\geq 3(\mathrm{OR}=4.01,95 \% \mathrm{Cl}: 2.51-6.41, P<0.001)$ neuropathy.

Conclusion: Nab-paclitaxel is effective for the treatment of non-metastatic breast cancer in the neoadjuvant setting. Nab-paclitaxel could improve pCR rate and EFS compared with sb-taxanes and with reasonable toxicities.
\end{abstract}

Keywords: Breast cancer, Neoadjuvant chemotherapy, Paclitaxel, Albumin-bound paclitaxel, Meta-analysis

\section{Background}

Breast cancer is the most common malignancy diagnosed in women worldwide $[1,2]$. Neoadjuvant chemotherapy is an established treatment to downstage inoperable or locally advanced cancers into operable cancers and to decrease the tumor size, and to allow

*Correspondence: shuwang@pkuph.edu.cn

Breast Center, Peking University People's Hospital, Beijing, China breast-conserving surgery [2-4]. In addition, neoadjuvant chemotherapy allows the assessment of the tumor response to systemic treatments before surgery [2]. Neoadjuvant chemotherapy has been shown to be at least equivalent to adjuvant chemotherapy in terms of survival [2]. A pathological complete response (pCR) is the best outcome that can be achieved after neoadjuvant chemotherapy and can predict the risk of recurrence [5]. The

C C The Author(s). 2021 Open Access This article is licensed under a Creative Commons Attribution 4.0 International License, which permits use, sharing, adaptation, distribution and reproduction in any medium or format, as long as you give appropriate credit to the original author(s) and the source, provide a link to the Creative Commons licence, and indicate if changes were made. The images or other third party material in this article are included in the article's Creative Commons licence, unless indicated otherwise in a credit line to the material. If material is not included in the article's Creative Commons licence and your intended use is not permitted by statutory regulation or exceeds the permitted use, you will need to obtain permission directly from the copyright holder. To view a copy of this licence, visit http://creativecommons.org/licenses/by/4.0/ The Creative Commons Public Domain Dedication waiver (http://creativecommons.org/publicdomain/zero/1.0/) applies to the data made available in this article, unless otherwise stated in a credit line to the data. 
Food and Drug Administration (FDA) and European Medicines Agency (EMA) have accepted pCR as an endpoint for accelerated drug approval in high-risk early breast cancer.

Conventional solvent-based (sb) taxanes (including paclitaxel and docetaxel) prevent cell proliferation by stabilizing the microtubules and are among the most widely used chemotherapy agents for breast cancer $[6$, 7]. In the neoadjuvant setting, a regimen of taxane-, alkylator-, and anthracycline-based chemotherapy is a standard-of-care for potentially operable breast cancer [2]. The addition of sb-taxanes to the alkylator-/anthracycline-based regimen improves the clinical response, pCR rate, disease-free survival (DFS), and overall survival (OS) [8]. However, sb-taxanes contain polyethylated castor oil and ethanol to increase the solubility of taxanes, so premedication and long infusion time are necessary to avoid hypersensitivity reactions $[9,10]$. In addition, the cremophor excipient traps paclitaxel in micelles, resulting in nonlinear pharmacokinetics $[11,12]$.

Nanoparticle albumin-bound paclitaxel (nab-paclitaxel) has been designed to avoid solvents and to achieve a higher delivery rate of paclitaxel to the tumors [13]. Several early clinical trials demonstrated that nabpaclitaxel was more effective than the sb-taxanes in the neoadjuvant setting for early breast cancer. And the treatment effect of nab-paclitaxel for breast cancer in the neoadjuvant setting was demonstrated in a previous meta-analysis in 2017, with a pooled pCR rate of $32 \%$, regardless of subtype [14]. However, most of the included studies were single-arm studies, and subgroup comparison was not made between sb-paclitaxel and nab-paclitaxel. Also, in the previous meta-analysis, only three randomized controlled trials (RCTs) were included and showed that using nab-paclitaxel instead of conventional sb-taxanes could improve the $\mathrm{pCR}$ rate, with reasonable toxicities [14]. Since 2017, new comparative clinical studies were reported about nab-paclitaxel versus sb-taxanes, and long-term outcomes have been updated for some previous trials [15-22]. Therefore, a comprehensive assessment of the effects of neoadjuvant nabpaclitaxel versus sb-taxanes in breast cancer treatment is needed. The aim of this meta-analysis was to compare the efficacy and safety of nab-paclitaxel versus sbtaxanes as neoadjuvant therapy in breast cancer, with subgroup analysis and long-term clinical outcomes included.

\section{Methods}

\section{Study design}

This was a systematic review and meta-analysis carried out according to the Preferred Reporting Items for Systematic Reviews and Meta-Analyses (PRISMA) guidelines. The PICO (Patient, Intervention, Comparison,
Outcome) process, a mnemonic used in evidence-based medicine [23], was used to searching for relevant articles, followed by screening on the basis of the inclusion and exclusion criteria. Study design, subject characteristics, treatment regimen, efficacy, and safety were extracted. All data were reviewed by two independent investigators according to a pre-specified protocol.

\section{Search strategy}

Two authors (YL and LSY) independently searched public databases, including PubMed, Embase, and Cochrane Central Register of Controlled Trial for available literature published up to September 2019. For the PubMed search, we used the MeSH terms 'breast neoplasm', 'neoadjuvant therapy', and 'albumin-bound paclitaxel', as well as other relevant key words. Supplementary Table S1 presents the full search strategies in detail. Abstracts from the American Society of Clinical Oncology (ASCO), the European Society of Medical Oncology Conference (ESMO), and the San Antonio Breast Cancer Symposium (SABCS) were retrieved using similar search terms. We also performed a manual search of the references from the identified articles. The selection and inclusion of the studies were performed in two stages, i.e., the analysis of titles and abstracts, followed by the full texts. Disagreements were resolved by a third author (LM).

\section{Eligibility criteria}

The studies were considered eligible in the presence of the following characteristics: 1) patients with breast cancer with an indication for taxane-based therapy as neoadjuvant chemotherapy; 2) intervention: nab-paclitaxel $\left(\right.$ Abraxane $\left.{ }^{\mathrm{Tn}}\right)$; 3) control: sb-taxane (paclitaxel or docetaxel); 4) study design: RCT or cohort study; 5) number of patients $\geq 30$; and 6) language was limited to English. All articles were screened independently by two authors (YL and LSY). For publications reporting on overlapping patients, duplicated records were removed. For multiple publications reporting the same study over time, the last updated data were used. To avoid publication bias, many meta-analyses also include the abstracts of renowned professional annual meetings like ASCO.

\section{Data extraction and quality assessment}

Data extraction was performed in two stages by two independent authors (YL and LSY). Disagreements were resolved by a third author (WS). Data including names of authors, publication year, study design, epidermal growth factor, and HR status, therapy regimen including dosage, pCR (ypT0 ypN0 or ypT0/is ypN0) rate, objective response rate (ORR) before surgery, event-free survival (EFS; event defined as disease progression during neoadjuvant treatment, recurrence, or death), OS 
(defined as the time from randomization to the date of death in clinical trials or duration of survival after diseases is diagnosed/treated in observational studies), and adverse events (AEs) were extracted using a structured data collection form. ORs of the primary outcome were collected if reported by the observational studies.

Quality assessment was evaluated according to the Cochrane risk bias tool for RCTs [24] and the Newcastle-Ottawa scale (NOS) [25] for observational studies. The Grading of recommendations, assessment, development, and evaluations (GRADE) approach was used to report the confidence of the estimates [26].

\section{Statistical analysis}

Odds ratio (OR) or hazard ratio (HR) and corresponding 95\% confidence intervals (CIs) were used to compare the outcomes, namely, post-neoadjuvant chemotherapy pCR, ORR, EFS, OS, and AEs. For studies reporting pCR in different definitions, ypT0 ypN0 was used over ypT0/is ypNO when reported. Statistical heterogeneity among studies was calculated by Cochran's $\mathrm{Q}$ test and the $\mathrm{I}^{2}$ index ( $>50 \%$ or $P<0.10$ indicate high heterogeneity) [27]. The random-effect model was used when high statistical heterogeneity was present among studies; otherwise, the fixed-effect model was applied [28]. In addition, the random-effect model was used as a sensitivity analysis for the justification of potential clinical or methodological heterogeneity. The consistency and quality of the results were assessed by sensitivity analysis. The potential publication bias was evaluated using a funnel plot and Egger's test [29]. $P$-values $<0.05$ were considered statistically significant. All analyses were performed using the STATA SE 14.0 package (StataCorp, College Station, Texas, USA). The analyses of the pathological complete response by different definitions for neoadjuvant therapy and the subgroup analyses of pathological complete response ( $\mathrm{pCR}$ ) for neoadjuvant nab-paclitaxel versus sb-taxanes in the treatment of breast cancer according to RCTs/non-RCTs, sb-taxane comparator, sb-paclitaxel, or sb-docetaxel, and HER2 and HR status were preplanned. All other analyses, including subgroups (TNBC, Ki-67, and different regimens) and secondary outcomes (ORR, OS, and EFS), were post hoc and data-driven.

\section{Results}

\section{Study retrieval and selection}

Fig. 1 presents the selection flowchart. The initial screening identified 406 papers that met the search parameters. After removing duplicates $(n=40$ papers) and excluding papers based on article type/study design $(n=$ 198 papers) and eligibility criteria ( $n=159$ papers), seven studies remained, including five RCTs [16, 17, 19-22] and two non-RCTs $[15,18]$ (Table 1). The number of patients per study ranged from 30 to 1206 in RCTs (total, $n=2667$ patients) and from 120 to 162 in nonRCTs (total, $n=282$ patients), with a total of 2949 patients across all studies. The age of the included patients ranged from 25 to 79 years. Human epidermal growth factor receptor 2 (HER2) status was reported by all seven studies. Sb-paclitaxel served as the comparator for nabpaclitaxel in five studies and sb-docetaxel in two. Five studies reported pCR by the definition of ypT0 ypN0, and five reported by the definition of ypT0/is ypN0 (Table 1). Untch et al., 2016 [20] and Gianni et al., 2018 [16] were included for pCR primary outcome, and longterm outcomes were extracted from Untch et al. 2019 [21] and Gianni et al., 2019 [30] for analyses. The median follow-up time from Untch et al. 2019 [21] was 49.6 months (range: $0.5-64$ months). In the two nonrandomized studies, Huang et al. 2015 [15] reported the unadjusted ORs, while Xie et al. 2019 [18] did not report any OR. The disease characteristics and doses of taxanes varied across studies, and the details are provided in Table 1.

\section{Comparison of efficacy based on $\mathrm{PCR}$}

Fig. 2 presents the forest plot of the pCR by different definitions [15-22]. In studies reporting $\mathrm{pCR}$ by ypT0 ypN0 ( $n=5$ studies), the pooled proportion of patients with pCR was $40.1 \%$ (429/1069) for nab-paclitaxel and $31.3 \%$ (333/1065) for sb-taxanes. In studies reporting pCR by ypT0/is ypNo ( $\mathrm{n}=5$ studies), the pooled proportion of patients with pCR was $33.2 \%(379 / 1140)$ for nabpaclitaxel and 26.4\% (315/1195) for sb-taxanes. The pCR rate was significantly higher in patients treated with neoadjuvant nab-paclitaxel than those with sb-taxanes regardless of the definition used (ypT0 ypN0: OR $=1.52$, 95\%CI: $1.27-1.83, P<0.001 ;$ ypT0/is ypN0: OR $=1.40$, 95\%CI: $1.17-1.68, P<0.001)$. Regarding the study by Moebus et al. [22], due to differences in both the drug used and the dosing schedule, we also showed subtotal OR (ypT0 ypN0: OR $=1.58,95 \%$ CI: $1.26-1.97$ ) by removing this study, and the conclusion of the metaanalysis did not change (Figs. 2).

\section{Comparison of efficacy in subgroups}

The $\mathrm{pCR}$ rate was significantly higher with nabpaclitaxel than sb-taxanes in RCTs ( $n=5$ studies) (pooled pCR: $36.9 \%$ vs. $29.2 \%$; OR $=1.45$, 95\%CI: $1.23-$ $1.72, \mathrm{P}<0.001)$, but not in non-RCTs $(n=2$ studies) (pooled pCR: $20.4 \%$ vs. $18.3 \%$; OR $=1.46,95 \%$ CI: $0.77-$ $2.78, P=0.177$ ) (Fig. 3a). Removing the study by Moebus et al. [22], the subtotal OR of RCTs was $1.47(95 \% \mathrm{CI}$ : 1.21-1.79). The benefit of nab-paclitaxel over sb-taxanes on pCR were also consistent across different comparators (sb-paclitaxel, $\mathrm{n}=5$ studies or sb-docetaxel, $\mathrm{n}=2$ studies) (Fig. 3b). 

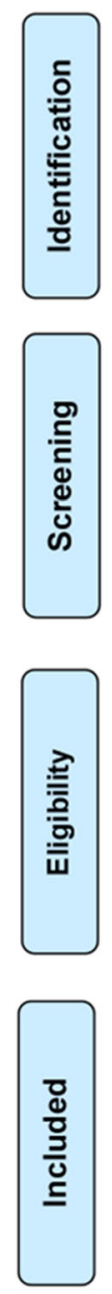

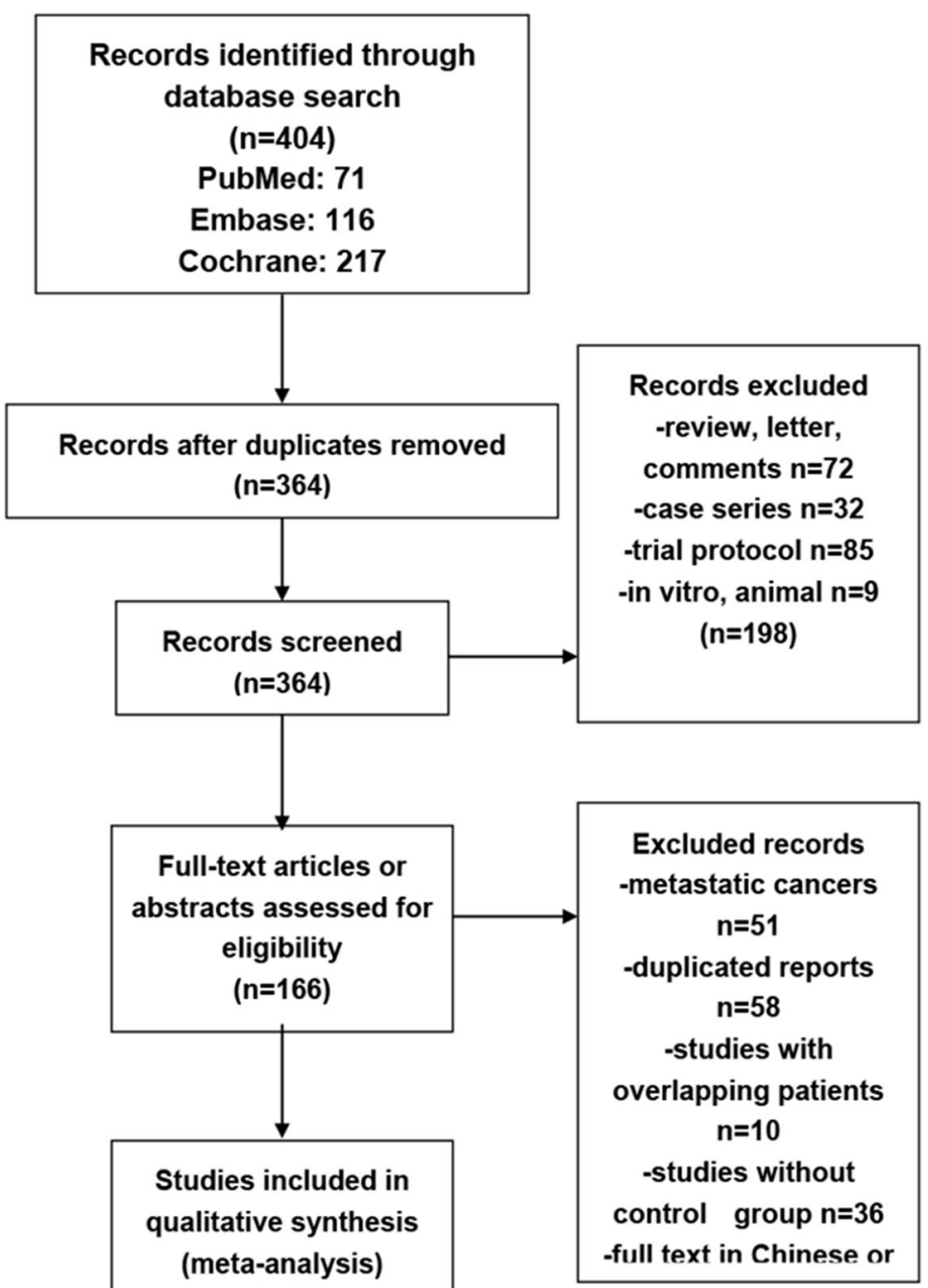

Fig. 1 Flowchart of the search process. RCT, randomized controlled trial

For subtype analysis, pCR benefits of nab-paclitaxel over sb-taxanes were observed in HER2-negative breast cancer ( $n=4$ studies) (pooled pCR: $23.9 \%$ vs. 16.3\%; $\mathrm{OR}=1.60,95 \% \mathrm{CI}: 1.26-2.03, P<0.001)$, HER2-negative HR-positive breast cancer ( $n=4$ studies) (pooled pCR: $14.2 \%$ vs. $9.8 \%$; OR $=1.53,95 \%$ CI: $1.07-2.19, P=0.020$ ), but not in HER2-positive breast cancer ( $n=3$ studies) (pooled pCR: $57.3 \%$ vs. $51.9 \%$; OR $=1.37$, 95\%CI: $0.95-$ 2.00, $P=0.096)$, HER2-positive HR-negative breast cancer $(\mathrm{n}=3$ studies) (pooled pCR: $66.3 \%$ vs. $68.2 \%$; OR $=$ 0.90, 95\%CI: $0.26-3.19, P=0.083$ ), and HER2-positive HR-positive breast cancer ( $\mathrm{n}=3$ studies) (pooled pCR: $52.8 \%$ vs. $45.5 \%$; $\mathrm{OR}=1.45,95 \% \mathrm{CI}: 0.93-2.26, P=0.104$ ) (Fig. 3c). For triple-negative breast cancer (TNBC) $(n=4$ studies), a trend of improved pCR was observed for nabpaclitaxel versus sb-taxanes $(43.8 \%$ vs. $29.5 \%$; $O R=1.86$,
95\%CI: $0.99-3.51, P=0.063$ ), and the strong benefits of nab-paclitaxel over sb-taxanes were observed in TNBC treated with $150 / 125 \mathrm{mg} / \mathrm{m}^{2}$ nab-paclitaxel in day 1,8 , 15 for four 3-week cycles $/ 260 \mathrm{mg} / \mathrm{m}^{2}$ four two-weekly cycles regimen ( $n=2$ studies) (pooled pCR: $48.0 \%$ vs. 24.4\%; OR $=2.95,95 \%$ CI: $1.54-5.67, P<0.001)$ but not with the $90 / 100 \mathrm{mg} / \mathrm{m}^{2}$ nab-paclitaxel in weeks 1,2 , and 3 , followed by a 1-week rest regimen ( $\mathrm{n}=2$ studies) (pooled pCR: $39.0 \%$ vs. $35.3 \%$; OR $=1.17$, $95 \% \mathrm{CI}$ : $0.71-$ 1.91, $P=0.534)$ (Fig. 3c and d).

For Ki-67 status, the benefits of nab-paclitaxel over sbtaxanes were observed in tumors with Ki-67 $>20 \%(n=3$ studies) (pooled pCR: $39.7 \%$ vs. $29.0 \%$; OR $=1.63$, 95\%CI: $1.26-2.12, \mathrm{P}<0.001)$, but not in tumors with Ki$67<20 \%$ ( $\mathrm{n}=3$ studies) (pooled pCR: $21.6 \%$ vs. $16.7 \%$; $\mathrm{OR}=1.41$, 95\%CI: $0.87-2.27, P=0.148)$ (Fig. 3e). 
Table 1 Literature search and study characteristics

\begin{tabular}{|c|c|c|c|c|c|c|c|c|c|c|c|}
\hline Authoryear & $\mathbf{n}$ & $\begin{array}{l}\text { Trial } \\
\text { type }\end{array}$ & Source & $\begin{array}{l}\text { Study } \\
\text { phase }\end{array}$ & Receptor status & $\begin{array}{l}\text { Taxane } \\
\text { dosage }\end{array}$ & $\begin{array}{l}\text { Neoadjuvant } \\
\text { Regimens }\end{array}$ & $\mathrm{n}$ & Age & Stage & $\begin{array}{l}\text { PCR } \\
\text { definition }\end{array}$ \\
\hline \multirow[t]{2}{*}{$\begin{array}{l}\text { Gianni } 2018 \\
{[16]}\end{array}$} & 695 & RCT & Full text & $\begin{array}{l}\text { Phase } \\
3\end{array}$ & HER2- & $\begin{array}{l}125 \mathrm{mg} / \mathrm{m}^{2} \\
\text { week 1,2,3, } \\
\mathrm{q} 4 \mathrm{w}^{*} 4\end{array}$ & $\begin{array}{l}\text { nab-p } \rightarrow \text { AC/ } \\
\text { EC/FEC }\end{array}$ & 346 & $\begin{array}{l}50 \\
(25- \\
79)\end{array}$ & $\|-\mid\|$ & \multirow[t]{2}{*}{$\begin{array}{l}\text { ypTO/is } \\
\text { ypNo }\end{array}$} \\
\hline & & & & & & $\begin{array}{l}90 \mathrm{mg} / \mathrm{m}^{2} \\
\text { week 1,2,3, } \\
\mathrm{q} 4 \mathrm{w}^{*} 4\end{array}$ & $\begin{array}{l}\mathrm{sb}-\mathrm{p} \rightarrow \mathrm{AC} / \mathrm{EC} / \\
\mathrm{FEC}\end{array}$ & 349 & $\begin{array}{l}50 \\
(25- \\
79)\end{array}$ & & \\
\hline \multirow[t]{2}{*}{$\begin{array}{l}\text { Kuwayama } \\
2018[17]\end{array}$} & 152 & RCT & Full text & $\begin{array}{l}\text { Phase } \\
2\end{array}$ & HER2- & $\begin{array}{l}100 \mathrm{mg} / \mathrm{m}^{2} \\
\mathrm{~d} 1,8,15 \\
\mathrm{q} 4 \mathrm{w}^{*} 4\end{array}$ & nab-p $\rightarrow$ FEC & 75 & $\begin{array}{l}49 \\
(32- \\
73)\end{array}$ & $|-|||$ & \multirow[t]{2}{*}{$\begin{array}{l}\text { ypTO } \\
\text { ypNO } \\
\text { ypTO/is } \\
\text { ypNo }\end{array}$} \\
\hline & & & & & & $\begin{array}{l}75 \mathrm{mg} / \mathrm{m}^{2} \\
\mathrm{q} 3 \mathrm{w}^{*} 4\end{array}$ & docetaxel $\rightarrow$ FEC & 77 & $\begin{array}{l}51 \\
(25- \\
68)\end{array}$ & & \\
\hline \multirow[t]{2}{*}{$\begin{array}{l}\text { Moebus } \\
2018 \text { [22] }\end{array}$} & 598 & $\mathrm{RCT}$ & Abstract & $\begin{array}{l}\text { Phase } \\
3\end{array}$ & $\begin{array}{l}\text { HER2+; TNBC; } \\
\text { luminal B-like; } \\
\text { luminal A-like: }\end{array}$ & $\begin{array}{l}330 \mathrm{mg} / \mathrm{m}^{2} \\
\mathrm{q} 2 \mathrm{w}^{*} 3\end{array}$ & $n a b-p+E C$ & 298 & $\begin{array}{l}49 \\
(20- \\
69)\end{array}$ & NA & \multirow[t]{2}{*}{$\begin{array}{l}\text { ypTO } \\
\text { ypNO }\end{array}$} \\
\hline & & & & & & $\begin{array}{l}60-100 \mathrm{mg} / \\
\mathrm{m}^{2} \mathrm{q} 2 \mathrm{w}^{*} 4\end{array}$ & docetaxel + EC & 300 & & & \\
\hline \multirow[t]{2}{*}{$\begin{array}{l}\text { Patel } 2019 \\
\text { [19] }\end{array}$} & 30 & $\mathrm{RCT}$ & Full text & $\begin{array}{l}\text { Phase } \\
2\end{array}$ & HER2+ & $\begin{array}{l}80 \mathrm{mg} / \mathrm{m}^{2} \\
q w^{*} 12\end{array}$ & $\begin{array}{l}\text { T-DM1 + L } \rightarrow \text { T- } \\
\text { DM1 + L + nab- } \\
p\end{array}$ & 14 & $\begin{array}{l}53.1 \\
(27.8- \\
69.7)\end{array}$ & II or III & \multirow[t]{2}{*}{$\begin{array}{l}\text { ypTO } \\
\text { ypNO }\end{array}$} \\
\hline & & & & & & $\begin{array}{l}80 \mathrm{mg} / \mathrm{m}^{2} \\
q w^{*} 12\end{array}$ & $\mathrm{TP} \rightarrow \mathrm{TP}+\mathrm{sb}-\mathrm{p}$ & 16 & $\begin{array}{l}57.2 \\
(39.6- \\
74.9)\end{array}$ & & \\
\hline \multirow[t]{2}{*}{$\begin{array}{l}\text { Untch } 2017 \\
{[20,21]}\end{array}$} & 1206 & $\mathrm{RCT}$ & Full text & $\begin{array}{l}\text { Phase } \\
3\end{array}$ & $\mathrm{HER} 2+/-; \mathrm{HR}+/-$ & $\begin{array}{l}150 \text { or } 125 \\
\mathrm{mg} / \mathrm{m}^{2} \mathrm{~d} 1,8 \\
15, \mathrm{q} 3 \mathrm{w}^{*} 4\end{array}$ & nab-p $\rightarrow$ EC & 606 & $\begin{array}{l}49 \\
(43- \\
57)\end{array}$ & $\begin{array}{l}\text { cT2 to cT4a-d or cT1c } \\
\text { with cN/HR-/HER2+/ } \\
\text { Ki67 > 20\% }\end{array}$ & \multirow{2}{*}{$\begin{array}{l}\text { ypT0 } \\
\text { ypNO } \\
\text { ypTO/is } \\
\text { ypNO } \\
\text { ypTO/is } \\
\text { ypNO/+ } \\
\text { ypTany } \\
\text { ypNO }\end{array}$} \\
\hline & & & & & & $\begin{array}{l}80 \mathrm{mg} / \mathrm{m}^{2} \mathrm{~d} 1, \\
8,15, \mathrm{q} 3 \mathrm{w}^{*} 4\end{array}$ & $s b-p \rightarrow E C$ & 600 & $\begin{array}{l}48 \\
(41- \\
56)\end{array}$ & & \\
\hline \multirow[t]{2}{*}{$\begin{array}{l}\text { Xie } 2019 \\
{[18]}\end{array}$} & 162 & $\begin{array}{l}\text { non- } \\
\text { RCT }\end{array}$ & Full text & NA & $\begin{array}{l}\text { HER2+/-; ER and/ } \\
\text { or PR+, HR- }\end{array}$ & $\begin{array}{l}260 \mathrm{mg} / \mathrm{m}^{2} \\
\mathrm{q} 2 \mathrm{w}^{*} 4\end{array}$ & $E C \rightarrow$ nab-p & 83 & $\begin{array}{l}47.8 \pm \\
11.2\end{array}$ & cT1-4, cN1-3 & \multirow{2}{*}{$\begin{array}{l}\text { ypTo } \\
\text { ypNo; } \\
\text { ypTo/is } \\
\text { ypNo }\end{array}$} \\
\hline & & & & & & $\begin{array}{l}175 \mathrm{mg} / \mathrm{m}^{2} \\
\mathrm{q} 2 \mathrm{w}^{*} 4\end{array}$ & $E C \rightarrow s b-p$ & 79 & $\begin{array}{l}52.1 \pm \\
10.4\end{array}$ & & \\
\hline \multirow[t]{2}{*}{$\begin{array}{l}\text { Huang } 2015 \\
\text { [15] }\end{array}$} & 120 & $\begin{array}{l}\text { non- } \\
\text { RCT }\end{array}$ & Full text & $\begin{array}{l}\text { Phase } \\
2\end{array}$ & HER2+/-; HR+/- & $\begin{array}{l}125 \mathrm{mg} / \mathrm{m}^{2} \\
\mathrm{qw} w^{*} 12\end{array}$ & $n a b-p+C b$ & 30 & $\begin{array}{l}49 \\
(29- \\
66)\end{array}$ & $|-|||$ & \multirow[t]{2}{*}{$\begin{array}{l}\text { ypT0/is } \\
\text { ypNo; } \\
\text { ypTo/is }\end{array}$} \\
\hline & & & & & & $\begin{array}{l}80 \mathrm{mg} / \mathrm{m}^{2} \\
q w^{*} 12\end{array}$ & paclitaxel + Cb & 90 & $\begin{array}{l}47.5 \\
(24- \\
71)\end{array}$ & & \\
\hline
\end{tabular}

Abbreviations: $A C$ doxorubicin/cyclophosphamide; $C b$ carboplatin; $C N$ clinically assessed axillary node stage; $C T$ clinically assessed tumor stage; $E C$ epirubicin/ cyclophosphamide; $E R$ estrogen receptor; FEC fluorouracil/epirubicin/cyclophosphamide; HER2 human epidermal growth factor receptor 2; HR hormone receptor; nab- $P$ nanoparticle albumin-bound paclitaxel; $P$ pertuzumab; $p C R$ pathologic complete response; $P R$ progesterone receptor; $2 \mathrm{w}$, every 2 weeks; $q 3 \mathrm{w}$, every 3 weeks; q4w, every 4 weeks; qw once weekly; $R C T$ randomized controlled trial; sb- $p$ solvent-based paclitaxel; $T$ trastuzumab; $T$-DM1 ado-trastuzumab emtansine; TNBC triple-negative breast cancer

\section{Comparison of efficacy based on ORR}

Among the seven studies, four (three RCTs, 2173 patients) had available data for ORR meta-analysis [15-17, 20, 21, 31]. Patients treated with nab-paclitaxel for breast cancer tended to have higher ORR than patients treated with sb-taxanes $(\mathrm{n}=3$ studies $)\left(\mathrm{I}^{2}=0.0 \%\right.$; $\mathrm{OR}=1.19$, 95\%CI: 0.97-1.46, $P=0.094$ ) (Fig. 4).

\section{Comparison of efficacy based on EFS and OS}

Among the seven studies, two RCTs (1901 patients) had available survival data for meta-analysis $[16,20,21]$. Nab-paclitaxel had an EFS benefit over sb-paclitaxel $\left(\mathrm{I}^{2}=48.5 \%\right.$; HR $=0.69,95 \%$ CI: 0.57-0.85, $\left.P<0.001\right)$ (Figure $\mathrm{S1A}$ ), but there was no statistically significant difference in $\mathrm{OS}\left(\mathrm{I}^{2}=0.0 \%\right.$; $\mathrm{OR}=0.79,95 \% \mathrm{CI}$ : $0.60-1.04, P=$ 0.092) (Figure S1B). 


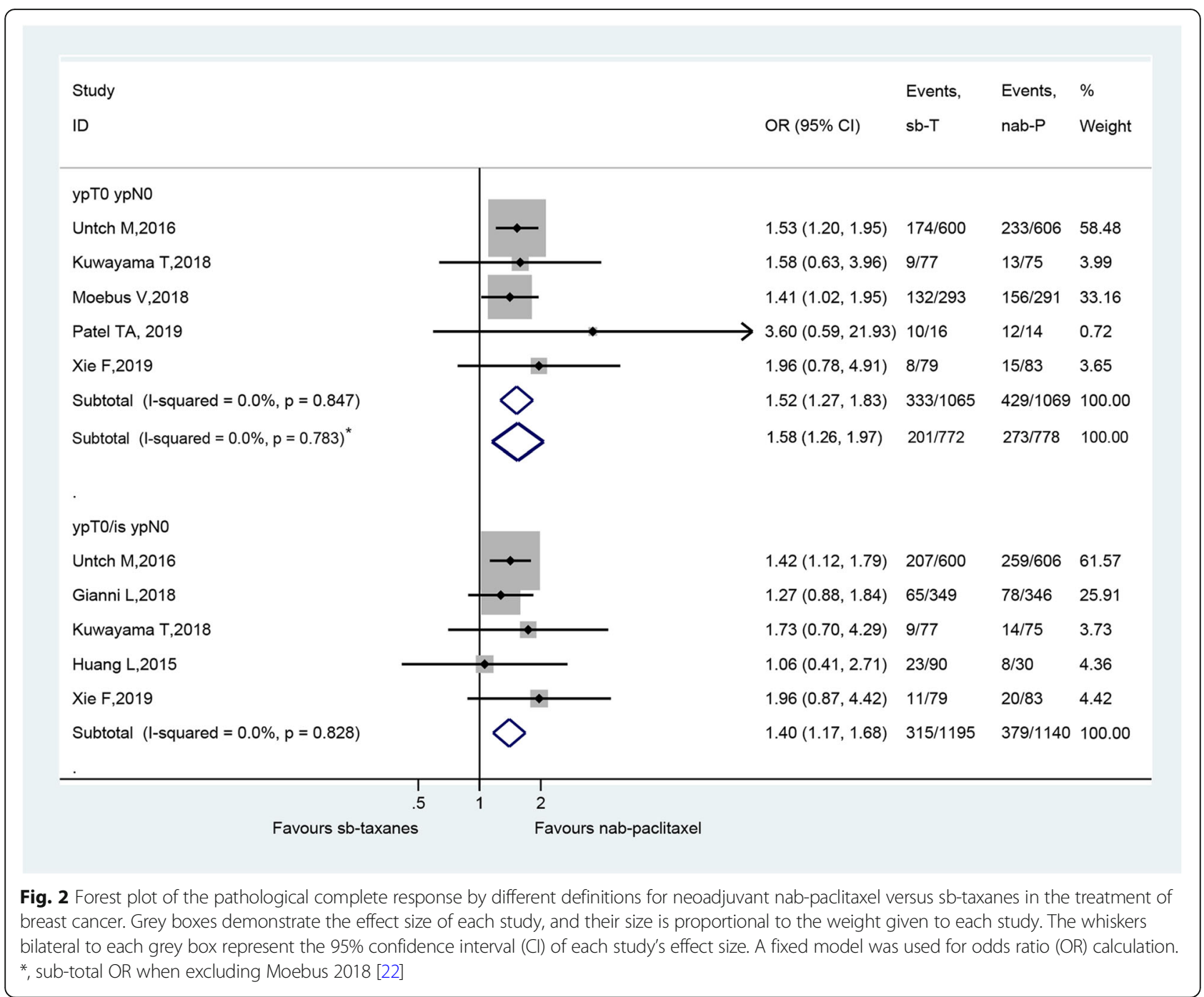

\section{Safety profile}

The results of all AEs and grade $>3$ AEs are listed in Table 2. There were no differences between nabpaclitaxel and sb-taxanes in terms of any-grade increased liver enzymes and liver function abnormalities, rash, arthralgia, alopecia, nausea, and vomiting (all $P>0.05$ ). Treatment with nab-paclitaxel was associated with increased occurrence of any-grade neuropathy, fatigue, diarrhea/constipation, neutropenia, myalgia, and anemia (all $P<0.05$ ) and reduced occurrence of any-grade hypersensitivity $(\mathrm{OR}=0.29,95 \% \mathrm{CI}$ : $0.11-0.72, P=0.008)$, compared with sb-taxanes. The occurrence of grade $\geq 3$ AEs was, in general, similar between the two treatment regimens, excluding neuropathy. The occurrence of grade $\geq 3$ neuropathy was higher in patients treated with nab-paclitaxel $(\mathrm{OR}=$ 4.01, 95\%CI: 2.51-6.41, $P<0.001)$ than with sbtaxanes.

\section{Quality assessment}

The results showed that the quality of the included studies ranged from moderate to high (Supplementary Figure S2 and Supplementary Table 2). For assessments of bias, five RCTs had low or unclear risk. Gianni et al. [16] and Untch et al. [20] had low risk for all bias. Kuwayama et al. [17] had unsure risk of bias for randomization, allocation concealment and other bias (without registration), Patel et al. [19] had an unsure risk of bias for randomization and allocation concealment, while Moebus et al. [22] had an unclear risk of bias for allocation concealment (Supplementary Figure S2). Both the NOS score of two observational studies was 9 , indicating that the included studies were with high quality (Supplementary Table 2).

\section{Sensitivity analyses of the primary outcome}

The sensitivity analysis showed that no significant alterations of the primary outcome were observed with the 


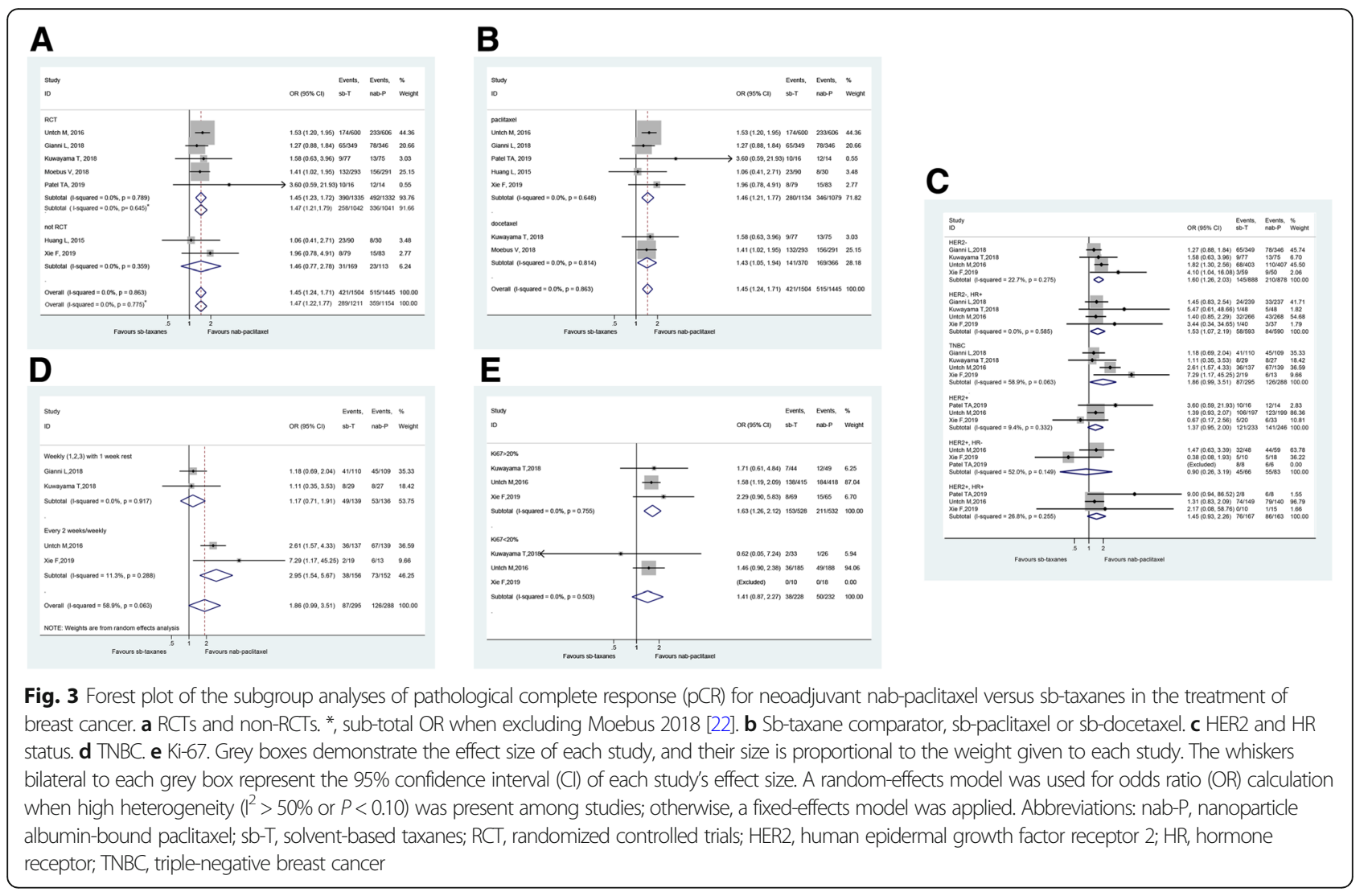

removal of one study, indicating that the results of pathological response in breast cancer patients who received nab-paclitaxel/sb-taxanes were relatively stable and reliable (Supplementary Figure S3). Selecting to use the random-effects or fixed-effects model for a metaanalysis based on the threshold of heterogeneity could be arbitrary. Thus, random-effects models were used to examine whether the results could be affected compared with the fixed-effects model. The results showed that the conclusion did not change (Supplementary Table S3).

\section{Quality of evidence}

Table 3 shows the assessments of each outcome under the evaluation of GRADE method. In terms of pCR, a low certainty on the estimates was assessed, yet the results also presented a critical importance for the employment of nab-paclitaxel. ORR and OS both presented a serious risk of imprecision regarding the outcome. Besides from its important level of evidence, the evaluation for ORR also demonstrated a very low certainty as well. As for OS, the assessment showed a moderate level of certainty and an important level of importance. Finally, the evaluation for EFS presented a high certainty and an important level of importance. Therefore, the confidence in the observed alterations is relatively low, future studies are encouraged to update the recommendations of this study.

\section{Publication bias}

Potential publication bias was assessed; there was no evidence of publication bias for the pooled analysis of pathological response and ORR (Supplementary Figure S4). It has to be noted that the assessment of publication bias is weak because of the small number of studies available for the funnel plot.

\section{Discussion}

Our study is the first meta-analysis that evaluated the effects of neoadjuvant nab-paclitaxel versus sb-taxanes for breast cancer and reported both short-term and longterm outcomes. The results showed that neoadjuvant nab-paclitaxel is effective and with reasonable toxicities.

The studies included in the present study analyzed patients with demographic and clinical characteristics similar to those of the studies included in the previous meta-analysis of neoadjuvant nab-paclitaxel [14]. Furthermore, the chemotherapies used with nab- or sbpaclitaxel were standard therapies supported by 


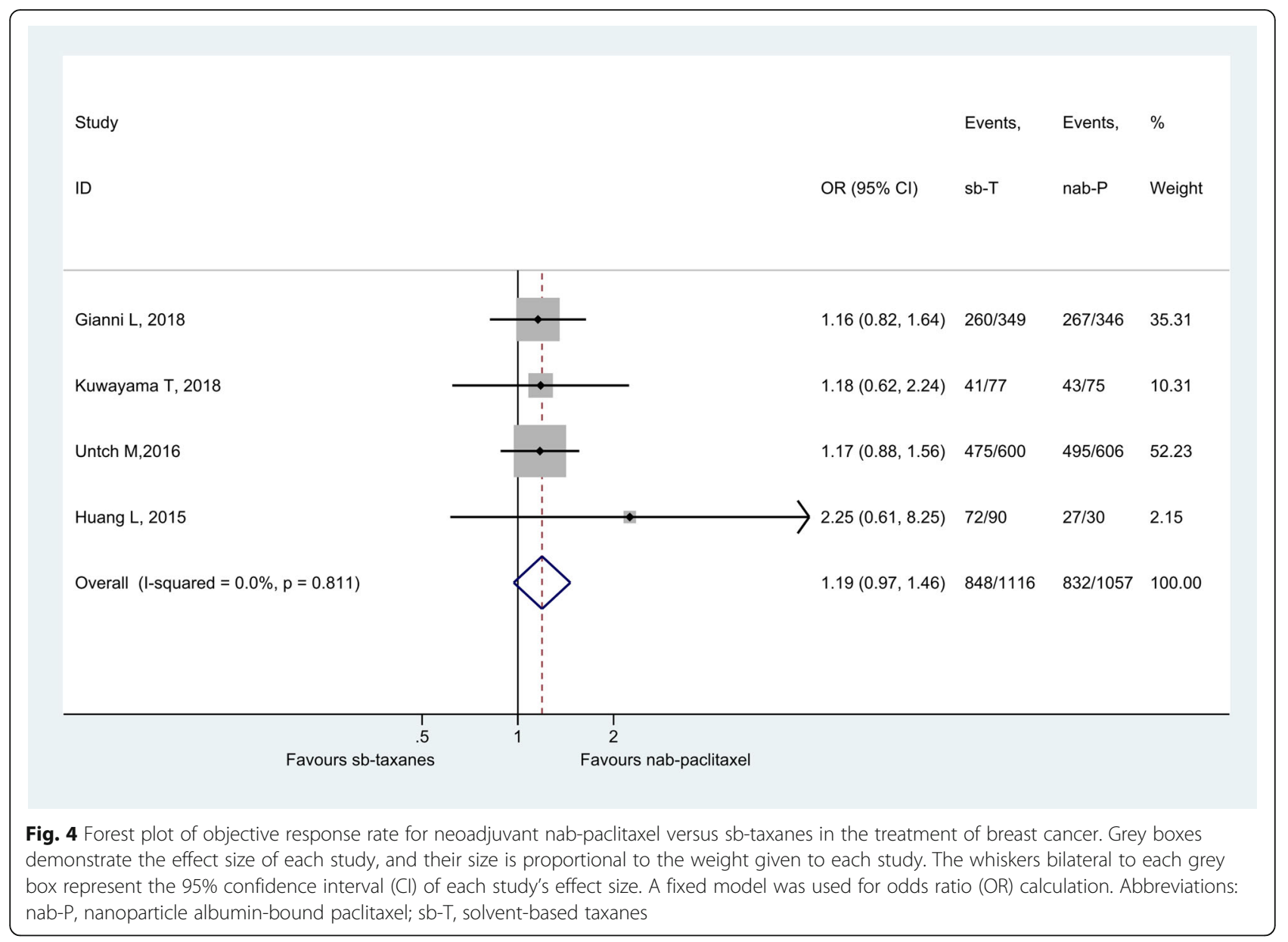

guidelines [2-4]. In the present meta-analysis, nabpaclitaxel was associated with a higher likelihood of achieving pCR compared with sb-taxanes, which is supported by the previous meta-analysis by Zong et al. [14]. The better efficacy observed for nab-paclitaxel might be due to the enhanced drug permeation and retention and to an increased local drug concentration at the tumor site [13, 32], which is achieved through receptormediated transcytosis [33]. Our results also showed that when using ypT0 ypN0 as pCR definition, the pooled proportion of patients with pCR $(40.1 \%$ for nabpaclitaxel and $31.3 \%$ for sb-taxanes) was a little higher (33.2\% for nab-paclitaxel and $26.4 \%$ for sb-taxanes) than when used ypT0/is ypN0 as pCR definition. This may due to not all used data in the two pCR definition arms that were from the same study. The variation in BC subtypes among different studies may contribute to this result. The trial by Gianni et al. (all patients with HER2negative disease and $68 \%$ was HR-positive, weight 25.91\%) used ypT0/is ypN0 as the definition for pCR outcome, whereas the trial by Moebus et al. (> 80\% patients with TNBC or HER2-positive disease, weight $33.16 \%$ ) used ypT0 ypN0 as the definition for pCR outcome. Indeed, we found that the pCR rates for nabpaclitaxel varied greatly across individual studies during our analysis, mainly attributed to the differences in patient and disease characteristics. Our subgroup analyses demonstrated that the $\mathrm{pCR}$ rates for nab-paclitaxel were higher in HER2-positive and TNBC patients and lower in HER2-negative, HR-positive patients, which is in line with the findings of Zong et al. [14]. Currently, the underlying mechanism for the modulation of response to taxanes by HR and HER2 in breast cancer is not entirely understood and requires further investigation [34]. However, higher pCR rates in the HER2-positive subtype may due to the use of HER2-targeted therapy, such as trastuzumab, etc. [35].

Paclitaxel every 2 weeks/weekly regimen is recommended by the National Comprehensive Cancer Network (NCCN) guideline for neoadjuvant treatment of TNBC, which is the most aggressive subtype of breast cancer [2]. Our results showed that neoadjuvant nab-paclitaxel had a higher $\mathrm{pCR}$ rate than neoadjuvant sb-taxanes when used weekly nab-paclitaxel in day 1, 8, 15 for four 3-week cycles/four two-weekly cycles regimen. This $\mathrm{pCR}$ rate for neoadjuvant nab-paclitaxel was also considerably higher 
Table 2 Adverse events

\begin{tabular}{|c|c|c|c|c|c|c|c|c|c|c|}
\hline & & & nab-P & & sb-T & & & & & \\
\hline & & $\mathbf{n}$ & Event & Total & Event & Total & OR $(95 \% \mathrm{Cl})$ & $P$ for $O R$ & $1^{2}$ & $P$ for $I^{2}$ \\
\hline Neuropathy & Any grade & 6 & 844 & 1127 & 676 & 1182 & $2.10(1.37,3.23)$ & 0.001 & 71.6 & 0.003 \\
\hline & Grade $\geq 3$ & 4 & 87 & 1083 & 23 & 1076 & $4.01(2.51,6.41)$ & $<0.001$ & 0.0 & 0.458 \\
\hline Increased ALT & Any grade & 2 & 364 & 942 & 379 & 936 & $0.91(0.74,1.12)$ & 0.356 & 42.3 & 0.188 \\
\hline & Grade $\geq 3$ & 2 & 16 & 942 & 17 & 936 & $0.93(0.47,1.86)$ & 0.846 & 61.0 & 0.109 \\
\hline Increased AST & Any grade & 2 & 250 & 942 & 235 & 936 & $1.09(0.87,1.36)$ & 0.451 & 0.9 & 0.315 \\
\hline & Grade $\geq 3$ & 2 & 6 & 942 & 6 & 936 & $0.99(0.33,2.96)$ & 0.991 & 32.5 & 0.224 \\
\hline Liver function abnormalities & Any grade & 1 & 11 & 14 & 9 & 16 & $2.85(0.57,14.33)$ & 0.203 & NA & NA \\
\hline & Grade $\geq 3$ & 1 & 2 & 14 & 0 & 16 & $6.60(0.29,150.07)$ & 0.236 & NA & NA \\
\hline Fatigue & Any grade & 4 & 670 & 1030 & 622 & 1029 & $1.27(1.04,1.55)$ & 0.018 & 0.0 & 0.495 \\
\hline & Grade $\geq 3$ & 4 & 39 & 1030 & 29 & 1029 & $1.35(0.83,2.20)$ & 0.225 & 0.0 & 0.622 \\
\hline Diarrhea/constipation & Any grade & 5 & 429 & 1060 & 420 & 1119 & $1.21(1.01,1.45)$ & 0.010 & 0.0 & 0.638 \\
\hline & Grade $\geq 3$ & 4 & 28 & 1046 & 22 & 1103 & $1.35(0.77,2.36)$ & 0.297 & 0.0 & 0.713 \\
\hline Rash & Any grade & 3 & 61 & 381 & 71 & 441 & $1.15(0.78,1.69)$ & 0.484 & 0.0 & 0.634 \\
\hline & Grade $\geq 3$ & 2 & 1 & 367 & 3 & 425 & $1.08(0.02,67.43)$ & 0.970 & 71.9 & 0.059 \\
\hline Neutropenia & Any grade & 5 & 765 & 1060 & 748 & 1119 & $1.53(1.24,1.89)$ & $<0.001$ & 0.9 & 0.401 \\
\hline & Grade $\geq 3$ & 4 & 528 & 1046 & 520 & 1103 & $1.33(0.74,2.39)$ & 0.333 & 81.2 & 0.001 \\
\hline Leucopenia & Any grade & 4 & 731 & 1046 & 766 & 1103 & $1.22(0.93,1.58)$ & 0.146 & 0.0 & 0.831 \\
\hline & Grade $\geq 3$ & 4 & 347 & 1046 & 353 & 1103 & $1.29(0.73,2.320)$ & 0.380 & 75.9 & 0.006 \\
\hline Hypersensitivity & Any grade & 1 & 6 & 337 & 20 & 335 & $0.29(0.11,0.72)$ & 0.008 & NA & NA \\
\hline & Grade $\geq 3$ & 1 & 1 & 337 & 2 & 335 & $0.50(0.04,5.49)$ & 0.567 & NA & NA \\
\hline Myalgia & Any grade & 2 & 211 & 679 & 176 & 678 & $1.29(1.02,1.63)$ & 0.036 & 0.0 & 0.334 \\
\hline & Grade $\geq 3$ & 1 & 2 & 679 & 0 & 678 & $4.98(0.24,104.02)$ & 0.3 & NA & NA \\
\hline Arthralgia & Any grade & 2 & 249 & 679 & 239 & 678 & $1.06(0.85,1.33)$ & 0.582 & 10.7 & 0.29 \\
\hline & Grade $\geq 3$ & 1 & 5 & 679 & 1 & 678 & $5.0(0.58,42.92)$ & 0.140 & NA & NA \\
\hline Alopecia & Any grade & 2 & 608 & 679 & 627 & 678 & $0.50(0.12,2.12)$ & 0.347 & 90.1 & 0.001 \\
\hline & Grade $\geq 3$ & 2 & 0 & 679 & 0 & 678 & NA & NA & NA & NA \\
\hline Anemia & Any grade & 2 & 588 & 635 & 597 & 691 & $1.86(1.28,2.71)$ & 0.001 & 23.3 & 0.254 \\
\hline & Grade $\geq 3$ & 2 & 18 & 635 & 7 & 691 & $3.89(1.55,9.72)$ & $<0.001$ & 0.0 & 0.547 \\
\hline Nausea & Any grade & 5 & 688 & 1060 & 738 & 1119 & $1.02(0.85,1.22)$ & 0.869 & 0.0 & 0.463 \\
\hline & Grade $\geq 3$ & 3 & 30 & 1046 & 28 & 1103 & $1.12(0.67,1.89)$ & 0.659 & 9.0 & 0.333 \\
\hline Vomiting & Any grade & 4 & 266 & 1046 & 299 & 1103 & $1.13(0.92,1.39)$ & 0.253 & 9.5 & 0.345 \\
\hline & Grade $\geq 3$ & 3 & 23 & 1046 & 19 & 1103 & $1.30(0.70,2.39)$ & 0.404 & 46.2 & 0.156 \\
\hline
\end{tabular}

Abbreviations: $A L T$ alanine aminotransferase; $A S T$ aspartare aminotransferase; $C l$ confidence interval; NA not applicable; nab- $P$ nanoparticle albumin-bound paclitaxel; $O R$ odds ratio; $s b-T$ solvent-based taxanes

than the overall pCR reported by a previous meta-analysis in TNBC patients treated with neoadjuvant chemotherapy [36]. In addition, our findings are consistent with the high response rates observed for nab-paclitaxel in the metastatic setting in TNBC [37, 38]. Despite a relatively low pCR rate for the HER2-negative, HR-positive breast cancer, pCR has been illustrated to be independently associated with patient prognosis regardless of cancer subtype [39]. A recent database study reported that neoadjuvant chemotherapy was more effective than neoadjuvant endocrine therapy in downstaging tumors in HER2-negative, estrogen receptor-positive locally advanced breast cancer [40]. Therefore, improved neoadjuvant chemotherapy efficacy might be especially beneficial in HER2-negative, HRpositive breast cancer. Our study found that nab-paclitaxel treatment was associated with a higher $\mathrm{pCR}$ rate than sbtaxanes for patients with HER2-negative, HR-positive disease. Regarding the proliferation index, patients with Ki$67>20 \%$ showed overall higher pCR rates than those with Ki- $67<20 \%$, as supported by a previous study [41]. Nabpaclitaxel showed better pCR rates in patients with Ki$67>20 \%$ compared with sb-taxanes, but not in patients 


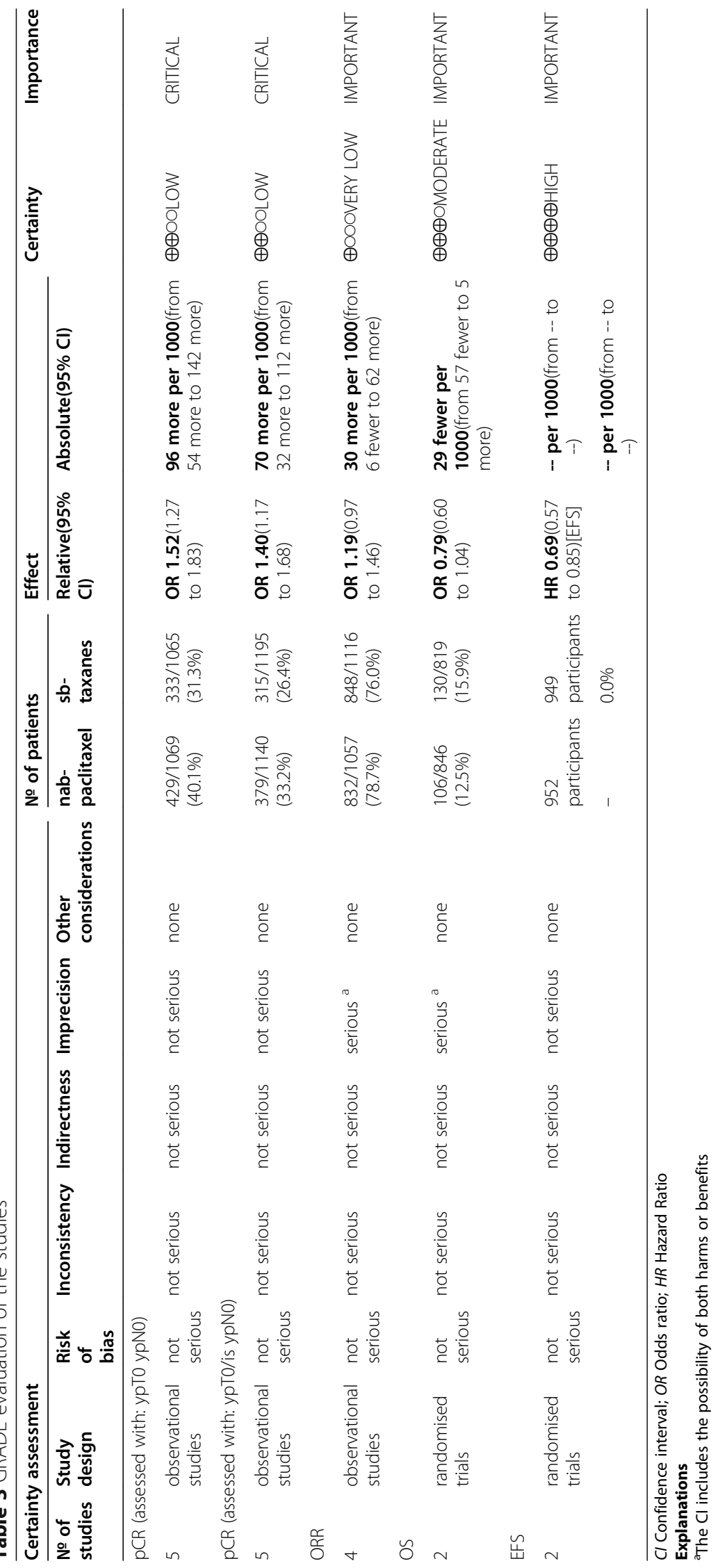


with Ki-67<20\%. Taken together, our data support the use of nab-paclitaxel as a reasonable treatment option for breast cancer in the neoadjuvant setting, especially in patients with HER2-negative HR-positive cancer and in highrisk patients (i.e., patients with TNBC and high Ki-67), but larger-scale confirmative studies are warranted.

$\mathrm{pCR}$ is a strong predictor for favorable long-term prognosis in breast cancer [42]. Nevertheless, it remains unclear how large a difference in pCR between nabpaclitaxel and sb-taxanes can translate into a difference in long-term clinical outcomes. With the recent availability of the 4-year outcome of the GeparSepto trial and the 5-year outcome of the ETNA trial, we could perform a pooled analysis of 1901 patients [21, 30]. The results showed that neoadjuvant nab-paclitaxel was associated with improved EFS compared with sb-taxanes. This improvement could be due, at least in part, to the fact that nanomedicine can better target cancer stem cells escaped from the primary tumor site, which are part of a subpopulation of tumor cells responsible for an important proportion of recurrences and metastases [43]. However, no statistically significant difference was observed for OS between the two treatments, though a trend of improved OS was noted for nab-paclitaxel. The lack of a more pronounced improvement in OS with nabpaclitaxel might be attributed to the availability of effective adjuvant therapy for early breast cancer and salvage regimens for metastatic breast cancer [2], which partially attenuated the effect of neoadjuvant treatments on OS. On the other hand, the power of our OS analysis was limited by the number of survival events. The overall low event number available for OS analysis at 4-5 years after neoadjuvant therapy further confirms the difficulty of incorporating OS as a primary endpoint in clinical trials for non-metastatic breast cancer.

In the present meta-analysis, there were no differences between nab-paclitaxel and sb-paclitaxel in most grade $>3$ AEs. Nevertheless, the incidence of grade $\geq 3$ neuropathies was higher with nab-paclitaxel, most likely due to the higher dose of paclitaxel administered/delivered with nab-paclitaxel than with sb-paclitaxel. These results are similar to those of Zong et al. [14], who showed that there were no differences in the toxicity profiles of nab-paclitaxel and sb-paclitaxel in terms of severe AEs, but that neuropathies were increased with nab-paclitaxel. Notably, the occurrence of any-grade hypersensitivity events is decreased using nab-paclitaxel despite the use of premedication for sb-taxanes. Therefore, this allows reductions in health care costs [44, 45]. Nevertheless, the meta-analysis of the safety data must be taken with caution as the number of studies that could be included was small, and heterogeneity was high.

This study has limitations. Not all the included studies were RCTs, leading to potential bias. The included studies were conducted at various institutions and in various countries and may have a potential bias in local cancer management policies and in reporting the types of adverse events. Importantly, different doses of nabpaclitaxel and comparator regimens were used in the included studies. In addition, different definitions of ORR were also used: 1) the proportion of patients who attain either a CR or a PR during the study, evaluated according to the RECIST criteria ( $v$ 1.1) purposely modified for this protocol and detailed in the SAP [16]; 2) using the Response Evaluation Criteria In Solid Tumors, version 1.0 [17]; 3) clinical response in breast and nodes was assessed after taxane treatment and before surgery and was defined by the modified WHO criteria [20]; or 4) the clinical tumor response was as a $\mathrm{CR}$ if there was no clinical evidence of palpable tumors in either the breast or axilla at the time of surgery, while a reduction of total tumor size by $>30 \%$ at the time of surgery was considered a PR [15].

Regarding survival, the EFS and OS results should be taken with caution because only two studies reported long term outcomes. Likewise, AEs results should be explained cautiously, due to some analyses of AEs were driven by only one study. Nevertheless, in the original study review process prior to data analysis, this study was eligible based on the inclusion/exclusion criteria, and, methodologically, it could not be excluded after the analysis. In addition, among the non-randomized studies, Huang et al. [15] reported the unadjusted ORs, while Xie et al. [18] did not report any OR. Therefore, the observational studies carry a risk of selection bias, indication bias, and immortal time bias, but those biases could not be controlled in the present meta-analysis. Only studies published in English were included, which is a bias. Publication bias is a major concern in all forms of meta-analysis, and it is likely that unpublished negative results were not included. The quality evaluation is also a concern, and quality evaluation is crude and somewhat subjective.

\section{Conclusion}

In conclusion, this meta-analysis suggests that compared with conventional sb-taxanes, neoadjuvant nab-paclitaxel could improve pCR rate and EFS in non-metastatic breast cancer and could be especially beneficial in the HER2negative HR-positive and high-risk disease types. In addition, the substitution of sb-taxanes with nab-paclitaxel is associated with reasonable toxicities.

\section{Supplementary Information}

The online version contains supplementary material available at https://doi. org/10.1186/s12885-021-07831-7.

Additional file 1: Supplementary Figure S1. Forest plot of event-free survival (A) and overall survival (B) for neoadjuvant nab-paclitaxel versus 
sb-paclitaxel in the treatment of breast cancer. Grey boxes demonstrate the effect size of each study, and their size is proportional to the weight given to each study. The whiskers bilateral to each grey box represent the $95 \%$ confidence interval (CI) of each study's effect size. A fixed model was used for hazard ratio (HR) or odds ratio (OR) calculation. Abbreviations: nab-P, nanoparticle albumin-bound paclitaxel; sb-T, solvent-based taxanes.

Additional file 2: Supplementary Figure S2. Methodological quality summary: review authors' judgments about each methodological quality item for included randomized controlled trials according to the Cochrane risk bias tool.

Additional file 3: Supplementary Figure S3. Sensitivity analysis of the primary outcome.

Additional file 4: Supplementary Figure S4. (A) Funnel plot of pathological complete response (pCR). (B) Funnel plot of objective response rate (ORR)

Additional file $\mathbf{5}$.

\section{Abbreviation}

RCTs: Randomized controlled trials; AEs: Adverse events; pCR: pathological complete response; FDA: Food and Drug Administration; EMA: European Medicines Agency; sb: solvent-based; DFS: Disease-free survival; OS: Overall survival; ASCO: American Society of Clinical Oncology; ESMO: European Society of Medical Oncology Conference; SABCS: San Antonio Breast Cancer Symposium; NOS: Newcastle-Ottawa scale; OR: Odds ratio; HR: Hazard ratio; Cls: Confidence intervals

\section{Acknowledgments}

None.

\section{Authors' contributions}

$M L$ and S W carried out the studies, participated in collecting data, analysis, or interpretation of data, and drafted the manuscript. $S L$ and $L Y$ performed the statistical analysis and participated in its design. All authors read and approved the final manuscript.

\section{Funding}

None.

\section{Availability of data and materials}

The datasets used and/or analyzed during the current study are available from the corresponding author on reasonable request.

\section{Ethics approval and consent to participate}

Not applicable.

\section{Consent for publication}

Not applicable.

\section{Competing interests}

All authors declare that they have no competing interests.

Received: 2 May 2020 Accepted: 24 January 2021

Published online: 04 February 2021

\section{References}

1. Harbeck N, Gnant M. Breast cancer. Lancet. 2017;389(10074):1134-50.

2. NCCN. Clinical practice guidelines in oncology (NCCN guidelines). Breast Cancer. Version 3.2019. Fort Washington: National Comprehensive Cancer Network; 2019

3. Senkus E, Kyriakides S, Ohno S, Penault-Llorca F, Poortmans P, Rutgers E, Zackrisson S, Cardoso F, Committee EG. Primary breast cancer: ESMO clinical practice guidelines for diagnosis, treatment and follow-up. Ann Oncol. 2015; 26(Suppl 5):v8-30.

4. Cardoso F, Costa A, Senkus E, Aapro M, Andre F, Barrios CH, Bergh J, Bhattacharyya G, Biganzoli L, Cardoso MJ, et al. 3rd ESO-ESMO international consensus guidelines for advanced breast Cancer (ABC 3). Ann Oncol. 2017; 28(1):16-33.
5. Battisti NML, True V, Chaabouni N, Chopra N, Lee K, Shepherd S, ShapiraRotenberg T, Joshi R, McGrath S, Okines A, et al. Pathological complete response to neoadjuvant systemic therapy in 789 early and locally advanced breast cancer patients: The Royal Marsden experience. Breast Cancer Res Treat. 2020;179(1):101-11.

6. Gines J, Sabater E, Martorell C, Grau M, Monroy M, Casado MA. Efficacy of taxanes as adjuvant treatment of breast cancer: a review and meta-analysis of randomised clinical trials. Clin Transl Oncol. 2011;13(7):485-98.

7. Ghersi D, Willson ML, Chan MM, Simes J, Donoghue E, Wilcken N. Taxanecontaining regimens for metastatic breast cancer. Cochrane Datab Syst Rev. 2015;6:CD003366

8. Trudeau M, Sinclair SE, Clemons M. Neoadjuvant taxanes in the treatment of non-metastatic breast cancer: a systematic review. Cancer Treat Rev. 2005; 31(4):283-302.

9. ten Tije AJ, Verweij J, Loos WJ, Sparreboom A. Pharmacological effects of formulation vehicles : implications for cancer chemotherapy. Clin Pharmacokinet. 2003:42(7):665-85.

10. Emens LA. Chemoimmunotherapy. Cancer J (Sudbury, Mass). 2010;16(4): 295-303.

11. Gianni L, Kearns CM, Giani A, Capri G, Vigano L, Lacatelli A, Bonadonna G, Egorin MJ. Nonlinear pharmacokinetics and metabolism of paclitaxel and its pharmacokinetic/pharmacodynamic relationships in humans. J Clin Oncol. 1995;13(1):180-90.

12. Gelderblom H, Verweij J, Nooter K, Sparreboom A. Cremophor EL: the drawbacks and advantages of vehicle selection for drug formulation. Eur J Cancer. 2001;37(13):1590-8.

13. Desai N, Trieu V, Yao Z, Louie L, Ci S, Yang A, Tao C, De T, Beals B, Dykes D, et al. Increased antitumor activity, intratumor paclitaxel concentrations, and endothelial cell transport of cremophor-free, albumin-bound paclitaxel, ABI007, compared with cremophor-based paclitaxel. Clin Cancer Res. 2006: 12(4):1317-24

14. Zong Y, Wu J, Shen K. Nanoparticle albumin-bound paclitaxel as neoadjuvant chemotherapy of breast cancer: a systematic review and metaanalysis. Oncotarget. 2017:8(10):17360-72.

15. Huang L, Chen S, Yao L, Liu G, Wu J, Shao Z. Phase II trial of weekly nabpaclitaxel and carboplatin treatment with or without trastuzumab as nonanthracycline neoadjuvant chemotherapy for locally advanced breast cancer. Int J Nanomedicine. 2015;10:1969-75.

16. Gianni L, Mansutti M, Anton A, Calvo L, Bisagni G, Bermejo B, Semiglazov V, Thill M, Chacon II, Chan A, et al. Comparing Neoadjuvant nab-paclitaxel vs paclitaxel both followed by Anthracycline regimens in women with ERBB2/ HER2-negative breast Cancer-the evaluating treatment with Neoadjuvant Abraxane (ETNA) trial: a randomized phase 3 clinical trial. JAMA Oncol. 2018; 4(3):302-8.

17. Kuwayama T, Nakamura S, Hayashi N, Takano T, Tsugawa K, Sato T, Kitani A, Okuyama H, Yamauchi H. Randomized multicenter phase II trial of Neoadjuvant therapy comparing weekly nab-paclitaxel followed by FEC with Docetaxel followed by FEC in HER2(-) early-stage breast Cancer. Clin Breast Cancer. 2018;18(6):474-80.

18. Xie F, Chen R, Zhang L, Yin Z, Zhu Q, You S, Jiang C, Li Y, Li S, Zha X, et al. Efficacy of two-weekly nanoparticle albumin-bound paclitaxel as neoadjuvant chemotherapy for breast cancer. Nanomedicine (Lond). 2019; 14(12):1595-603.

19. Patel TA, Ensor JE, Creamer SL, Boone T, Rodriguez AA, Niravath PA, Darcourt JG, Meisel JL, Li X, Zhao J, et al. A randomized, controlled phase II trial of neoadjuvant ado-trastuzumab emtansine, lapatinib, and nabpaclitaxel versus trastuzumab, pertuzumab, and paclitaxel in HER2-positive breast cancer (TEAL study). Breast Cancer Res. 2019;21(1):100.

20. Untch M, Jackisch C, Schneeweiss A, Conrad B, Aktas B, Denkert C, Eidtmann $\mathrm{H}$, Wiebringhaus $\mathrm{H}$, Kummel S, Hilfrich J, et al. Nab-paclitaxel versus solvent-based paclitaxel in neoadjuvant chemotherapy for early breast cancer (GeparSepto-GBG 69): a randomised, phase 3 trial. Lancet Oncol. 2016;17(3):345-56.

21. Untch M, Jackisch C, Schneeweiss A, Schmatloch S, Aktas B, Denkert C, Schem C, Wiebringhaus H, Kummel S, Warm M, et al. NAB-paclitaxel improves disease-free survival in early breast Cancer: GBG 69-GeparSepto. J Clin Oncol. 2019;37(25):2226-34.

22. Moebus V, Noeding S, Ladda E, Klare P, Schmidt M, Schneeweiss A, Janni W Marmé F, Reimer T, Schmatloch S, et al. Neo-/adjuvant phase III trial to compare intense dose-dense (idd) treatment with EnPC to tailored dosedense (dt) therapy with dtEC-dtD for patients with high-risk early breast 
cancer: Results on pathological complete response ( $\mathrm{pCR}$ ) for patients treated within the neoadjuvant setting. J Clin Oncol. 2018;36(15_suppl):568.

23. Huang $X$, Lin J, Demner-Fushman D. Evaluation of PICO as a knowledge representation for clinical questions. AMIA Annual Symposium proceedings AMIA Symposium; 2006. p. 359-63.

24. Higgins JP, Altman DG, Gotzsche PC, Juni P, Moher D, Oxman AD, Savovic J, Schulz KF, Weeks L, Sterne JA. The Cochrane Collaboration's tool for assessing risk of bias in randomised trials. BMJ (Clinical research ed). 2011; 343:d5928.

25. Deeks JJ, Dinnes J, D'Amico R, Sowden AJ, Sakarovitch C, Song F. Evaluating non-randomised intervention studies. Health Technol Assess. 2003;7(27):27.

26. Guyatt GH, Oxman AD, Schunemann HJ, Tugwell P, Knottnerus A. GRADE guidelines: a new series of articles in the journal of clinical epidemiology. J Clin Epidemiol. 2011;64(4):380-2.

27. Higgins JP, Thompson SG, Deeks JJ, Altman DG. Measuring inconsistency in meta-analyses. BMJ (Clinical research ed). 2003;327(7414):557-60.

28. Deeks JJ, Higgins JP, Altman DG. Analyzing data and undertaking metaanalyses. In: Cochrane Handbook for Systematic Reviews of Interventions 501. Edn. Edited by Higgins JP, green S. Oxford: The Cochrane Collaboration; 2008.

29. Kelley GA, Kelley KS. Statistical models for meta-analysis: a brief tutorial. World J Methodol. 2012;2(4):27-32.

30. Gianni L, Mansutti M, Anton A, Martínez LC, Bisagni G, Bermejo B, Semiglazov V, Thill M, Chacon Jl, Chan A, et al. Event-free survival analysis of the prospectively randomized phase III ETNA study with neoadjuvant nabpaclitaxel (nab-P) versus paclitaxel (P) followed by anthracycline regimens in women with HER2-negative high-risk breast cancer. J Clin Oncol. 2019; 37(15_suppl):515.

31. Martin M, Chacon Jl, Anton A, Plazaola A, Garcia-Martinez E, Segui MA, Sanchez-Rovira P, Palacios J, Calvo L, Esteban C, et al. Neoadjuvant therapy with weekly nanoparticle albumin-bound paclitaxel for luminal early breast Cancer patients: results from the NABRAX study (GEICAM/2011-02), a multicenter, non-randomized, phase II trial, with a companion biomarker analysis. Oncologist. 2017;22(11):1301-8.

32. Desai N, Trieu V, Damascelli B, Soon-Shiong P. SPARC expression correlates with tumor response to albumin-bound paclitaxel in head and neck Cancer patients. Transl Oncol. 2009;2(2):59-64.

33. Yardley DA. Nab-paclitaxel mechanisms of action and delivery. J Controlled Release. 2013;170(3):365-72.

34. Azambuja E, Durbecq V, Rosa DD, Colozza M, Larsimont D, Piccart-Gebhart M, Cardoso F. HER-2 overexpression/amplification and its interaction with taxane-based therapy in breast cancer. Ann Oncol. 2008;19(2):223-32.

35. Figueroa-Magalhães MC, Jelovac D, Connolly R, Wolff AC. Treatment of HER2-positive breast cancer. Breast (Edinburgh, Scotland). 2014;23(2):128-36.

36. Wu K, Yang Q, Liu Y, Wu A, Yang Z. Meta-analysis on the association between pathologic complete response and triple-negative breast cancer after neoadjuvant chemotherapy. World J Surg Oncol. 2014;12:95.

37. Hamilton E, Kimmick G, Hopkins J, Marcom PK, Rocha G, Welch R, Broadwater G, Blackwell K. Nab-paclitaxel/bevacizumab/carboplatin chemotherapy in first-line triple negative metastatic breast cancer. Clin Breast Cancer. 2013;13(6):416-20.

38. Lobo C, Lopes G, Baez O, Castrellon A, Ferrell A, Higgins C, Hurley E, Hurley J, Reis I, Richman $S$, et al. Final results of a phase II study of nab-paclitaxel, bevacizumab, and gemcitabine as first-line therapy for patients with HER2negative metastatic breast cancer. Breast Cancer Res Treat. 2010;123(2):427-35.

39. Cortazar P, Zhang L, Untch M, Mehta K, Costantino JP, Wolmark N, Bonnefoi H, Cameron D, Gianni L, Valagussa P, et al. Pathological complete response and long-term clinical benefit in breast cancer: the CTNeoBC pooled analysis. Lancet. 2014;384(9938):164-72.

40. LeVasseur N, Willemsma KA, Li H, Gondara L, Yip WC, Illmann C, Chia SK Simmons C. Efficacy of Neoadjuvant endocrine therapy versus Neoadjuvant chemotherapy in ER-positive breast Cancer: results from a prospective institutional database. Clin Breast Cancer. 2019;19(6):e683-9.

41. Yerushalmi R, Woods R, Ravdin PM, Hayes MM, Gelmon KA. Ki67 in breast cancer: prognostic and predictive potential. Lancet Oncol. 2010;11(2):174-83.

42. Kong X, Moran MS, Zhang N, Haffty B, Yang Q. Meta-analysis confirms achieving pathological complete response after neoadjuvant chemotherapy predicts favourable prognosis for breast cancer patients. Eur J Cancer. 2011; 47(14):2084-90.

43. Gener P, Gouveia LP, Sabat GR, de Sousa Rafael DF, Fort NB, Arranja A, Fernandez Y, Prieto RM, Ortega JS, Arango D, et al. Fluorescent CSC models evidence that targeted nanomedicines improve treatment sensitivity of breast and colon cancer stem cells. Nanomedicine. 2015;11(8):1883-92.

44. Dranitsaris G, Coleman R, Gradishar W, et al. Breast Cancer Res Treat. 2010; 119(3):717-24.

45. Dranitsaris G, Cottrell W, Spirovski B, Hopkins S. Economic analysis of albumin-bound paclitaxel for the treatment of metastatic breast cancer. J Oncol Pharmacy Practice. 2009;15(2):67-78.

\section{Publisher's Note}

Springer Nature remains neutral with regard to jurisdictional claims in published maps and institutional affiliations.
Ready to submit your research? Choose BMC and benefit from:

- fast, convenient online submission

- thorough peer review by experienced researchers in your field

- rapid publication on acceptance

- support for research data, including large and complex data types

- gold Open Access which fosters wider collaboration and increased citations

- maximum visibility for your research: over $100 \mathrm{M}$ website views per year

At BMC, research is always in progress.

Learn more biomedcentral.com/submissions 